UDK 528.73

\title{
REQUIREMENTS FOR AERIAL PHOTOGRAPHY
}

\author{
Birutė Ruzgienė \\ Dept of Geodesy and Cadastre, Vilnius Gediminas Technical University, \\ Sauletekio al. 11, LT-10223 Vilnius-40, Lietuva, \\ e-mail:Birute.Ruzgiene@ap.vtu.lt
}

Received 2405 2004, accepted 14062004

\begin{abstract}
The photogrammetric mapping process at the first stage requires planning of aerial photography. Aerial photographs quality depends on the successfull photographic mission specified by requirements that meet not only Lithuanian needs, but also the requirements of the European Union. For such a purpose the detailed specifications for aerial photographic mission for mapping urban territories at a large scale are investigated. The aerial photography parameters and requirements for flight planning, photographic strips, overlaps, aerial camera and film are outlined. The scale of photography, flying height and method for photogrammetric mapping is foreseen as well as tolerances of photographs tilt and swings round (yaw) are presented. Digital camera based on CCD sensors and on-board GPS is greatly appreciated in present-day technologies undertaking aerial mission.
\end{abstract}

Keywords: aerial photography, photogrammetric surveying, parameters, on-board GPS, calibration.

\section{Introduction}

The present-day photogrammetry has influenced survey practice drastically because of its successful application as a mapping tool. Photogrammetric surveying is a measurement system comprised of photographs taken by a precise camera and measured by stereo instruments. Photogrammetric measurements are used for densification of horizontal and vertical control.

A photogrammetric mapping process includes: obtaining aerial photography, completing ground control network, constructing map from photos, checking the compiled map data for compliance with project specification. The ground control points to be measured by photogrammetry should be signalised before the flight. The photogrammetric survey should encompass (ideally) a minimum of eight horizontal control points that should be spaced no father apart than seven photos base and four vertical points spaced around the perimeter of the area. The horizontal control points should have an order higher than the intended order of the topographic survey.

The decision to use photogrammetric methods in mapping is primarily economic, although workload and project deadline requirements have to be considered. As the areas mapped increase, the cost for photogrammetric mapping decreases; also, use of photogrammetry to extent ground control becomes feasible. It is assumed that the mapped area must exceed 20 hectares if photogrammetrc mapping costs were to be competitive with ground surveying techniques.

In addition, in many areas periods of time acceptable for aerial photography are quite limited by weather and ground cover conditions which are related to the season of year. It can cause expensive delay on the project for which the aerial photography were ordered.

Aerial photographs specifically for mapping purposes must meet the requirements of a very high quality. It depends on successful photographic mission that must be carefully planned and executed. Prior to the photo flight the mapping specifications must be determined and meet the photogrammetric instrument requirements.

A flight planning which includes specifications for a project can be prepared after careful consideration of many variables influencing the quality of aerial photography.

The aim is, after investigation of the experience of taking aerial photography in Lithuania as well as abroad, to specify requirements of aerial photography for urban territories mapping at a large scale such as 1:1000 $1: 2000$. The scale of aerial photography is foreseen 1:5000 or 1:6000 and, applying analogical camera, the focal length $c=210 \mathrm{~mm}$. It is intended to produce colour aerial photographs and the chosen method of phtogrammetric mapping is orthophotography.

The quality of the aerial photographs is the main consideration in selecting techniques.

\section{Parameters of aerial photography}

A flight planning consists of a flight (navigation) map which shows where the aerial photographs are to be taken and parameters (specifications) which outlines the specific requirements such as aerial camera and film requirements, scale, flying height, end lap, side lap, tilt and swing round (yaw) tolerances, etc [1]. 
For the flight plan drawing a good topographic map is to be provided. The digital Base Map of Lithuania at a scale 1:50 000 on the basis of the license can be used.

The number of map sheets corresponds to 1:10 000 scale map sheet subdivision in Lithuanian state coordinate system $L K S$-94, each map sheet being of size $5 \times 5 \mathrm{~km}$. The map at a scale 1:1000 and 1:2000 sheet's size respectively will be $0,5 \times 0,5 \mathrm{~km}$ and $1 \times 1 \mathrm{~km}$, dividing map sheet at the scale 1:10 000 into 100 and 25 units.

Flight planning must ensure photographic coverage of the entire area to be mapped in a minimum air time. Any obstacles to flying and any prohibited areas over which flights are forbidden or only allowed under strict precautions, such as military training areas, etc are to be investigated. A permission to carry out the aerial photography is given by the National Land Service.

Flight lines. The photogrammetric survey should be aerial. Single flight lines (strips) of photography usually are not acceptable. Photographic strips shall be flown East-West or North-South direction. All flight lines must be as straight and parallel as possible. The lack of parallelism between adjacent strips has to be within $5^{0}$ (difference between bearings of adjacent strips). Breaks in strip continuity are allowed only by weather conditions and care on the damage of aircraft or when change in flight altitude is required. Flight line deviation from straight path shall not exceed $2 \%$ of the flight path length. Allowed flight lines deviations from planned path measured on the aerial photographs should not exceed $15 \mathrm{~mm}$. Tilt and drift of aerial photographs should not exceed $\pm 2^{0}$ and yaw - up to $\pm 5^{0}$ when measured between the base line and the line parallel to the frame of the photograph, nor create stereoscopic gaps in the photography [2].

Global Positioning System (GPS) is of great help to ensure that the photographs are really aimed at correct points [3].

Overlap. The photographs overlap shall be sufficient to obtain stereoscopic coverage. The overlap in line flight shall be average $65 \%$ (not less than $60 \%$ and not more than $70 \%)$. The overlap of parallel strips of photography (side lap) shall average $40 \%$ [2]:

$$
Q=40+60 \frac{h}{H}=42 \% \approx 40 \%,
$$

where $H$ - flying height $(1050 \mathrm{~m}), h$ - maximal heights difference regarding to mean object plane (10-40 m).

When side lap is specified, any side lap less than $25 \%$ or more than $50 \%$ shall be considered sufficient grounds for rejecting all photographs on that flight line.

Such defined overlaps of taken aerial photography for urban territories are appointed to the third class of the first order photogrammetric specification, referring to presented specifications applied to analytic photogrammetric methods (Table 1), where photogrammetric procedures are divided in to orders (second and third) and classes (first and second for each order) [1].
Time of photography. Photography shall be undertaken only when lighting and weather conditions are acceptable for photographs. The calendar time for aerial photography shall be from the end of March to the beginning of May. Photography is not to be attempted by haze, smoke or dust, or clouds. It may be taken at any suitable solar altitude above $30^{\circ}$. Taking aerial photography in urban territories is better at midday, when shadows are shortest.

\section{Technical means}

Before taking aerial photographs technical means (aircraft, camera and photo film) are to be selected and adjusted between as well with photography operating (flying height, speed, shatter, exposure), in order to provide forward motion of images (2).

Aircraft. The aircraft is to be of type suitable for performing the photography specified.

The surfaces of camera port glass shall be of optical quality (have appropriate spectral transmission characteristics) and be kept clean and free of scratches.

The aircraft shall be equipped with a calibrated altimeter for determination of flight altitude. A record of outside air temperature and the altimeter settings shall be maintained for each flight line when air temperature varies more than $2{ }^{\circ} \mathrm{C}$. The actual height declination of the aerial photography above the average aerial photography bar plane shall not exceed $3 \%$ of the projected height. Temperature and humidity should be controlled in the aircraft and camera compartment maintained according to the guidelines of the manufacturer's instructions.

The camera shall be insulated from the vibration of the aircraft by levelling the camera in flight and compensating for the aircraft.

Projection centre coordinates of photographs are to be taken by on-board GPS that reduce the number of ground control points. During the aerial photography dual frequency GPS receiver and equivalent ground based receiver (one or two) shall be logged or by getting GPS data from permanent GPS station. GPS data are collected at one-second intervals and after processing presented in an appropriate format (RINEX).

Cameras. A metric camera is to take photographs of targets and features in the field. The camera should be at least the quality of those employed for large-scale mapping.

The cameras used shall be precision metric survey cameras or digital optical with image $23 \times 23 \mathrm{~cm}$ size and with forward motion compensation.

The metric camera should be calibrated every 2 years and after repair or modifications. Characteristics of its internal orientation parameters: radial symmetric distortion, decentred lens distortion, principal point and point of symmetry coordinates and reseau coordinates should be determined using calibration techniques [4]. These defined parameters are corrected to the measured image coordinates. The asymmetry of the radial distortion measured on four diagonals from lens axis to 
edge of field shall be such that the largest absolute difference between measured radial distortion and average radial distortion shall not exceed $0,005 \mathrm{~mm}$. The maximum decentring distortion measured in the focal plane shall not exceed $0,010 \mathrm{~mm}$. Table 1 shows specifications for metric camera calibration as well.

It is recommended undertaking aerial photography for urban territory by using the camera of normal field of view $43,5^{\circ}-53,5^{\circ}$ and with mean focal length $c=210 \pm$ 5 mm (eg, Wild RC 30, Zeiss TOP 30 or LMK 2000).

The film or sensor shall be held in the focal plane. Fiducial marks shall be provided such as to produce and define positions on every negative or digital image as well arranged at the focal plane. Lines joining two opposite fiducial marks shall intersect at $90^{\circ}$ within \pm 1 '. Fiducial marks situated in the corners of the format neither shall nor project more than $2 \mathrm{~cm}$, measured from the corner. Fiducial marks on the sides of the format shall not project more than $1 \mathrm{~cm}$ into the $23 \times 23 \mathrm{~cm}$ area.

The camera shutter shall be of the between-the-lens variable speed type, so that light is transmitted simultaneously to all parts of the format when the shutter is open. The efficiency of the shutter shall be at least $70 \%$ at the maximum aperture.

Light filter shall be of optical glass, free of bubbles, striation and scratches. The surface of any filter shall be plane-parallel within 10".

A platen should be included into which the film have be satisfactorily flattened during exposure. The time interval between exposures and the longest duration of exposure is defined regarding to camera parameters and aircraft flying speed. The film plane illumination is stipulated in manufacturer's instructions. The indistinct of points at photographic images appears because of forward motion during the fly of aircraft.

Forward motion of photographs shall be calculated according to formulae [5]:

$$
\delta=0,7 \frac{W}{H} c t
$$

where $W$ - aircraft flying speed, $H$ - height of flying ( $H$ $=1050 \mathrm{~m}), c=210 \mathrm{~mm}, t-$ exposure. When $W=250 \mathrm{~km} / \mathrm{h}$ and $t=1 / 500 \mathrm{~s}$, then $\delta=0,019 \mathrm{~mm}$ shall be appointed.

Table 1. Specifications for aerial photography the applying analytic method

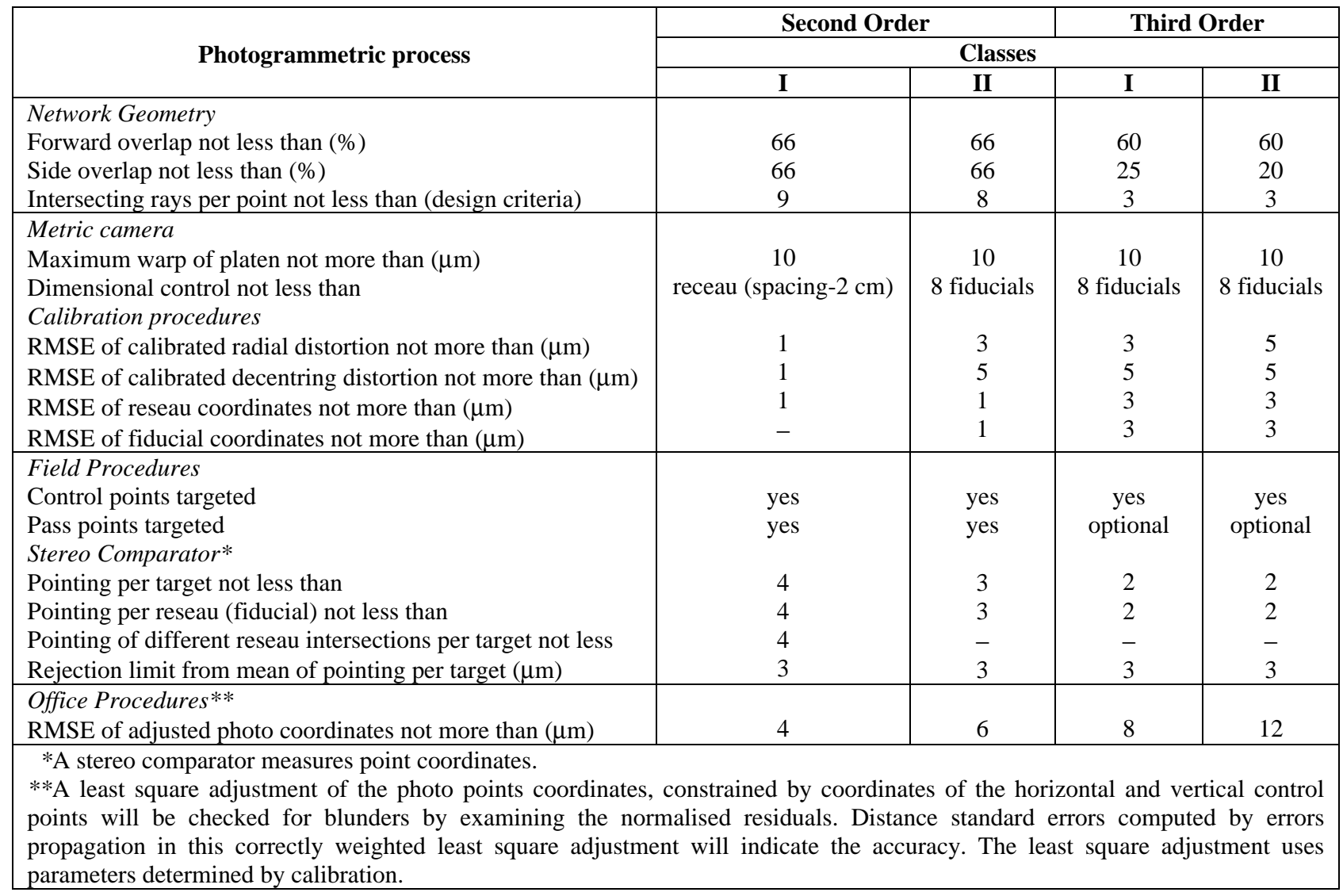


The resolving power or resolution $(\mathrm{R})$ is expressed in lines or pairs per $\mathrm{mm}(\mathrm{L} / \mathrm{mm})$ and specifies how many lines per $\mathrm{mm}$ can just be distinguished from adjacent spaces of equal width. The resolving power of the lens shall be such that the resolution is a minimum of 40 lines pairs per millimeter from the centre to a field angle of $40^{\circ} \cdot R=1 / 2 d$, there $d$ - number of lines pairs per mm.

In order to prevent too optimistic or pessimistic figures for resolution, a value known as the area weighted average resolution (AWAR) is adopted [6]. Example of $A W A R$ calculation is presented in Fig 1 and Table 2.

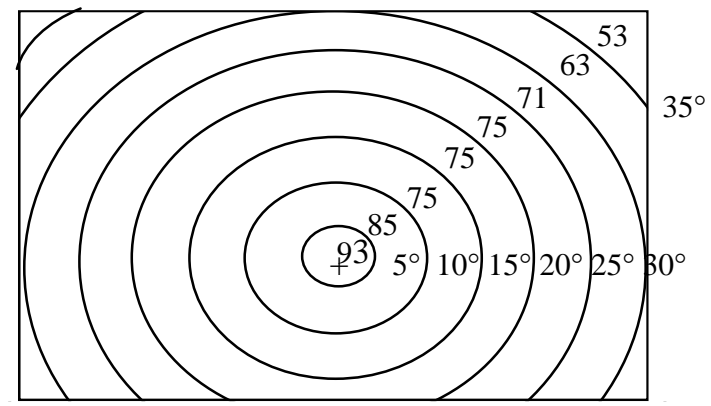

Fig 1. Area weighted resolution of the aerial camera Wild P31: the geometric mean of resolution computed for each ring

Table 2. Area weighted average resolution calculation

\begin{tabular}{|c|c|}
\hline Area A, mm & Mean $\mathbf{~}, \mathbf{L} / \mathbf{m m}$ \\
\hline 230 & 93 \\
730 & 85 \\
1280 & 75 \\
1660 & 75 \\
1990 & 75 \\
2420 & 71 \\
1640 & 63 \\
580 & 53 \\
\hline$\sum A=10530$ & $\sum(A \cdot R)=759070$ \\
\hline \multicolumn{2}{|c|}{$A W A R=\left(\sum(A \cdot R) /\left(\sum A\right)=72 \mathrm{~L} / \mathrm{mm}\right.$} \\
\hline
\end{tabular}

The area weighted average resolution shall be a minimum of 60 line pairs per $\mathrm{mm}$ undertaking aerial photography for urban area.

Digital cameras. Transiting from analytical to digital photogrammetry is well-advanced techniques possibilities of digital photogrammetric cameras. Presentday technology can provide digital cameras based on static field of CCD sensors (Charge Coupled Device) [7, 8]. The CCD can vary in storage capacity and resolution, which affects the clarity of the digital imgage. Two technologies are available as the basis of airborne digital sensors - linear and area array CCDs (Fig 2) [9, 10].

Three main products of scanning systems are mostly used:

1. Linear scanner - ADS 40, Leica (Switzerland);

2. Area array sensor - DMS, Z/I Imagine (USA, Germany), DIMAC, Cicade (Belgium);

3. UltraCam, Vexel (Austria). a)

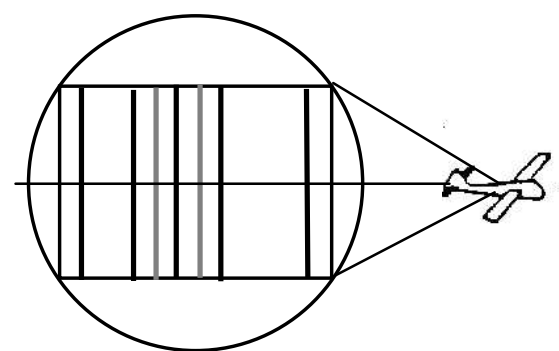

b)

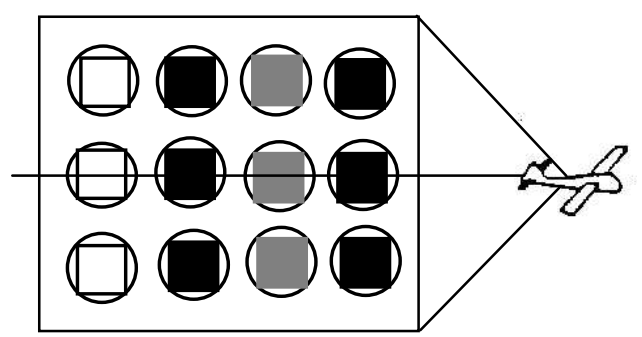

Fig 2. Scanning methods used at digital aerial camera systems: a) linear $C C D$, b) $C C D$ matrices (surface arrays)

Some desirable technical data of digital camera are [11]:

a) The size of sensor (resolution) shall be not less than $4000 \times 4000$ pixels;

b) Size of pixels on terrain -10 or $20 \mathrm{~cm}$, depending of mapping scale;

c) Focal length required for city surveys;

d) Multispectral $I R$ colour image storage capacity $(R G B)-25$ bits for each colour;

e) Formats of digital images: TIF-RGB, TIFCMYK, JPEG, IMG or HLML.

One of advantages of direct data capture in the air by digital camera system is the possibility of capturing multispectral data as well as panchromatic. Applying the digital camera, the efficiency of digital photogrammetry increases by $25-40 \%$ and reduces the price particularly when large area of aerial photography. The negative factor of digital camera usage is expensiveness $(\sim 1,5$ million Euros), short focal lengths as well.

The usage of digital camera system for aerial photography of Lithuanian urban territory shall be foreseen in future.

Aerial films. In case of conventional optical photography only dimensional stable polyester base unexpired negative colour film shall be used. The film base, excluding the emulsion, shall not be less than 0,10 $\mathrm{mm}$ in thinness and $24,1 \mathrm{~cm}$ in width. The negative colour film is a three-layer colour film emulsion category with blue, green and red sensitive layers which, when processed, produce a colour negative.

In case of digital optical photogrammetry the technical characteristics of sensors employed in detail shall be indicated.

Delivery of materials. The materials shall be delivered not later than 30 days after photography mission has been taken place.

The index map shall be prepared based on the adjusted GPS camera exposure centres. It shall contain 
the location of each flight line, outlined photographs and included ground control points used in aerial photography.

The materials to be delivered to final designation are:

- All accepted and rejected processed films or digital raw data;

- One set of contact prints of each image;

- Index map;

- $\quad$ GPS coordinate report;

- Camera calibration report;

- Operational report;

- Quality assurance reports;

- Material used for flight planning during preparatory stage.

Final acceptance of a project will be made after checking up all delivered materials at the designated final designation.

\section{Conclusions}

The developed requirements for aerial photography are adopted for getting very high quality of aerial photographs at a flight mission for urban territory's photogrammetric mapping at a large scale such as 1: 1000 or 1: 2000.

Projecting aerial flights for photographic mission appointed parameters are: the camera lens cone should be with focal lengths $210 \mathrm{~mm}$; the photo scale is desired at 1:5000, depending to contracting authority agreement the photo scale should be at 1: 6000 or 1:8000; departures from flight heights to produce the recommended aerial photographs scale should not exceed $3 \%$.

Recent advances in CCD development, computer processing and data storage capacities are beginning to make digital camera system competitive with analog systems for many projects.

In a case of digital optical photography the processing of the raw digital data requires new techniques that are drastically aimed at the increasing overlaps of parallel strips of photography up to $60 \%$ and forward overlap between adjacent photos in the line of flight to 80-90\%.

In Lithuania the digital optical photography is greatly recommended for taking digital images, which would be used for photogrammetric mapping in future.

\section{References}

1. The Surveying Handbook (Edited by Russell C. C. Brinker and Roy Minnick). Boston/Dordrecht/London: Kluwer Academic Publishers, 2001. 929 p.

2. Technical regulation of requirements. GKTR.13.01.:2001. Terms of references for aerial photography. Technical requirements of geodesy and cartography. (Geodezijos ir kartografijos techniniai reglamentai). Vilnius: National Land Service at the Ministry of Agriculture, 2001. 14 p (in Lithuanian).

3. Ruzgienè, B. Determination of inner orientation parameters of digital camera. Geodesy and Cartography (Geodezija ir kartografija), Vol XXVIII, No 2. Vilnius: Technika, 2002, p 45-49 (in Lithuanian).

4. Ruzgienè. B.; Žalnierukas, A. Aerial triangulation using kinematic GPS data. Geodesy and Cartography.
(Geodezija ir kartografija), Vol XXIV, No 1. Vilnius: Technika, 1998, p 16-25 (in Lithuanian).

5. Aržanov, E. P.; Iljin, V. B. Means of aerial photography. (Аэрофотосъемочное оборудование). Moscow: Nedra, 1972. 183 p (in Russian).

6. Kraus, K. Photogrammetry. Vol 1. Fundamentals and standard processes. Köln: Dümmler, 2000. 396 p.

7. Falkner, E.; Morgan, D. Aerial mapping. Methods and applications. London, New York, Washington: Lewis Publishers, 2002. 190 p.

8. Kraus, K. Photogrammetry. Vol 2. Advanced methods and applications. Bonn: Dümmler, 1997. 466 p.

9. Fricker, P.; Sandau, R.; Walker S. Digital photogrammetric cameras: possibilities and problems. Photogrammetric week'99. Stuttgart: Wichman Verlag, Heidelberg, 1999, p 71-82.

10. Schenek, T. Digital photogrammetry. Vol 1. USA, Laurelville, OH: TerraScience, 1999. 428 p.

11. RMK TOP - Aerial survey camera system. http://www.ziimaging.com/Products/AerialCameraSystem s/RMK_Top.htm

\section{REIKALAVIMAI, KELIAMI AEROFOTONUOTRAUKAI}

\section{B. Ruzgienè}

S a n tra u a

Pirmuoju fotogrametrinio kartografavimo etapu parengiamas projektas žemès paviršiui aerofotografuoti. Aerofotonuotraukos kokybė priklauso nuo aerofotografavimo proceso sèkmingumo, t. y. fotogrametrinių reikalavimų, keliamų aerofotonuotraukai, tinkamo igyvendinimo - ne tik pagal Lietuvos poreikius, bet ir Europos Sajungos nuostatas.

Pateikiami tikslingiausi aerofotonuotraukos parametrai skaitmeniniams spalvotiems 1:1000 arba 1:2000 masteliu nuotraukos Lietuvos miestų ortofotografiniams žemèlapiams sudaryti. Rengiant urbanizuotų teritorijų aerofotografavimo parametrus ir siekiant gauti geros kokybès, tikslius ortofotografinius žemèlapius, remtasi literatūros šaltiniais, Lietuvos ir kai kurių užsienio šalių institucijų patirtimi. Aeronuotrauka projektuojama 1:5000 arba 1:6000 mastelio, aerofotokameros židinio nuotolis $c=210 \mathrm{~mm}$.

Pateikti tinkamo aerofotografavimo reikalavimai: aerofotonuotraukų tarpusavio sanklota, maršrutų nuokrypiai, aerofotografiniu vaizdų polinkiai, aerofotografavimo sąlygos. Nurodytos aerofotografavimo techninès priemonès: orlaivio ypatumai, aerofotografavimo kameru parametrai. Aerofotoaparato skiriamajai gebai apibrèžti taikyta svertinè vidutinè skiriamoji geba (1 pav., 2 lentelè).

Kadangi vis dažniau skaitmeninès aerofotokameros naudojamos topografijos poreikiams, todèl kitu Lietuvos urbanizuotų teritorijų aerofotogrametrinio kartografavimo etapu numatoma taikyti ir skaitmeninę aerofotografavimo sistemą.

Raktažodžiai: aerofotografavimas, fotogrametrinė nuotrauka, parametrai, lèktuvų GPS, kalibravimas. 